Fikrah: Jurnal Ilmu Aqidah dan Studi Keagamaan

issn c2354-6174 eissn 2476-9649

Tersedia online di: journal.iainkudus.ac.id/index.php/fikrah

Volume 9 Nomor 1 2021, (149-164)

DOI: 10.21043/fikrah.v8i1. 10465

\title{
Niqab Perspektif Mahasiswi IAIN Surakarta: Pemahaman terhadap Teks dan Praktik Bercadar
}

\author{
Ari Hikmawati \\ Institut Agama Islam Negeri Surakarta, Indonesia \\ ari.hikmawati@iain-surakarta.ac.id \\ Zaenal Muttaqin \\ Institut Agama Islam Negeri Surakarta, Indonesia \\ zenmuttaqin@gmail.com \\ Moh Abdul Kholiq Hasan \\ Institut Agama Islam Negeri Surakarta, Indonesia \\ hasanuniversitas@gmail.com
}

\begin{abstract}
This paper discussed the motives of wearing niqab among Muslim women. Most of Muslim women wear niqab because of religious motives. However, the development of niqab recently brings up a variety of colours and models. This diversity indicates different motives among Muslim women in wearing niqab. Surveying IAIN Surakarta's students who wear niqab, this research elaborated the relationship between their motives of wearing niqab and their understanding of Islamic teaching about niqab. The research found that even though the main motive to wear niqab is to observe religious teaching, IAIN Surakarta's students who wear niqab also consider the practice for safety reasons. They also realize that wearing niqab is not an obligation in Islam and follow schools which consider it as preferable (sunah).
\end{abstract}

Keywords: context, motive, niqab, religious text 


\begin{abstract}
Abstrak
Artikel ini membahas pemakaian cadar di kalangan muslimah. Motif utama para muslimah memakai cadar adalah untuk menjalankan ajaran agama. Namun yang sedang marak akhir-akhir ini adalah banyaknya variasi model dan warna dalam pemakaian cadar. Variasi ini mengindikasikan adanya aspek-aspek lain yang turut mengiringi pemakaian cadar di kalangan para muslimah. Dengan melakukan survey terhadap mahasiswa IAIN Surakarta yang memakai cadar, penelitian ini membahas hubungan motif bercadar dengan pemahaman terhadap ajaran tentang cadar. Penelitian ini menunjukkan bahwa meski faktor pengamalan ajaran agama merupakan motif utama para responden untuk memakai cadar, para mahasiswi IAIN Surakarta yang memakai cadar memiliki motif untuk keamanan. Mereka juga mengetahui dan menyadari bahwa memakai cadar bukanlah sebuah kewajiban dan mengikuti pendapat bahwa memakai cadar adalah dianjurkan (sunah).
\end{abstract}

Kata Kunci: cadar, motif, konteks, teks keagamaan

\title{
Pendahuluan
}

Niqab adalah istilah yang digunakan untuk menyebut kain penutup muka bagi perempuan yang berhijab. Jika secara umum muslimah berbusana muslim dengan membiarkan wajah terbuka, muslimah yang memakai niqab, selain berjilbab, ia juga memakai kain untuk menutup wajahnya. Jumhur ulama bersepakat akan wajibnya muslimah untuk berjilbab sebagai sarana untuk menutup aurat. Secara umum, aurat perempuan yang harus ditutup adalah seluruh tubuh kecuali muka dan telapak tangan. Meskipun jumhur ulama menetapkan bahwa wajah bukan merupakan aurat perempuan, bagi sebagian muslim, wajah adalah aurat perempuan yang harus ditutup (Harahap, 2019; Rasyid \& Bukido, 2018; Ulumuddin, 2020).

Penutup wajah ini dalam istilah Bahasa Arab disebut sebagai niqab, sebagaimana dalam QS. Al-Ahzab: 59. Sementara itu, dalam Bahasa Indonesia digunakan kata cadar untuk menyebut niqab. Penggunaan cadar di Indonesia baru merebak dalam satu dasawarsa terakhir, melengkapi sejarah panjang pemakaian jilbab di Indonesia. Meski baru merebak dalam kurun waktu sepuluh tahun terakhir, bukan berarti perempuan muslimah Indonesia tidak ada yang memakai cadar sebelumnya. Sejarah panjang jilbab di Indonesia diawali dengan kerudung yang masih menyisakan bagian leher dan rambut perempuan terbuka. Sejak tahun 1980-an, jilbab berkembang dengan model yang lebih tertutup, leher dan rambut perempuan ikut ditutup. Pemakaian cadar juga sudah mulai ada meski tidak sesemarak sekarang ini. 
Di IAIN Surakarta juga terdapat fenomena mahasiswi bercadar. Dalam observasi awal, ada sekitar 50 mahasiswi yang bercadar yang tersebar di seluruh fakultas. Biasanya pemakaian bercadar selalu dihubungkan dengan pemahaman keagamaan yang mengharuskan menutup muka di tempat umum (Zempi, 2016). Selain itu, identifikasi dan afiliasi kepada kelompok keagamaan tertentu juga bisa menjadi alasan seorang muslimah untuk memakai cadar (Shirazi \& Mishra, 2010). Meski motif pemahaman dan pengamalan agama mungkin menjadi faktor utama pemakaian cadar oleh para mahasiswi tersebut, namun penelitian ini akan menelusuri faktor-faktor lain yang ikut memberi pengaruh terhadap pemakaian cadar. Oleh karena itu, artikel ini akan membahas pemakaian cadar di lingkungan mahasiswi IAIN Surakarta dari perspektif pemahaman mereka tentang hukum bercadar dan praktek mereka dalam bercadar.

\section{Cadar dalam Tinjauan Hukum Islam}

Niqab (cadar) adalah salah satu model bagi muslimah dalam menutupi aurat. Ada yang menyebut cadar adalah tambahan bagi perempuan muslimah dalam berjilbab. Namun ada pula yang menganggap cadar sebagai sebuah keharusan. Perbedaan pendapat ini tidak sampai pada perbedaan tentang kewajiban menutup bagi muslimah menutup aurat dengan berjilbab ('Audah, 2000; Yusra, 2013). Dalam Islam jilbab dimaknai sebagai pakaian longgar yang menutupi seluruh tubuh wanita dari ujung kepala hingga ujung kaki. Ini mengindikasikan bahwasannya jilbab bukan hanya kain yang menutupi kepala hingga dada, bukan pula kain yang hanya digantungkan di pundak, atau kain yang hanya menutup sebagian rambut bagian belakang saja bukan pula kopyah yang hanya menutup kepala sedangkan lehernya masih terbuka bukan pula kain kecil yang hanya mampu menutup bagian ujung kepala bagian.

Letak perbedaan antara kerudung (khimar), jilbab dan hijab adalah pada bentuk fisik dan fungsinya. Kerudung adalah kain panjang yang fungsinya hanya untuk menutup bagian kepala hingga dada. Dasar hukum diwajibkannya muslimah memakai kerudung adalah dalam Q.S. an-Nür ayat 31. Ayat ini tidak secara eksplisit menyebutkan perempuan untuk memakai penutup kepala. Minimal ada dua redaksi yang dipahami oleh para ulama tentang ketentuan memakai kerudung atau penutup kepala, yaitu terkait dengan frase "Dan hendaklah mereka menutupkan kain kerudung ke dada mereka" dan "janganlah menampakkan perhiasan mereka kecuali kepada...tentang aurat wanita". Batasan tentang aurat juga sebenarnya ada perbedaan pendapat dari para ulama. 
Ayat tersebut menggunakan redaksi khimar yang dicirikan harus menutup hingga dada. Sehingga istilah khimar ini dalam bahasa Indonesia disebut dengan kerudung yaitu kain panjang yang menutup kepala dan menjulur hingga dada. Sedangkan istilah jilbab lebih kompleks daripada kerudung karena ia menutup semua aurat wanita bukan hanya kepala hingga dada bahkan lebih dari itu yaitu dari ujung kepala hingga ujung kaki.

Penelitian tentang cadar yang mengambil aspek hukum Islam sebagai sudut pandangnya dilakukan oleh Rasyid dan Bukido (2018), Harahap (2019) dan Ulumuddin (2020). Penelitian-penelitian ini membahas perbedaan pendapat di kalangan ulama tentang penggunaan cadar. Penelitian-penelitian ini menyatakan bahwa pendapat para ulama tentang wajib dan tidaknya memakai cadar bagi para muslimah tergantung pada konteks di mana dan kapan ulama tersebut hidup. Para ulama biasanya merujuk pada anggapan bahwa pemakaian cadar di masa Nabi adalah sebagai identitas yang membedakan perempuan muslimah dan tidak, serta antara perempuan merdeka dan budak. Sementara penelitian-penelitian lain banyak membahas tentang aspek-aspek sosial dari dampak bercadar, pendekatan teori identitas, maupun penelitian-penelitian fenomonologis terkait muslimah-muslimah bercadar (Cahyaningrum \& Desiningrum, 2017; Dewi, 2019; Rahman \& Syafiq, 2017; Saleh et al., 2019; Vristiandani \& Rakhmad, 2019; Zulfa \& Junaidi, 2019). Berbeda dengan penelitian-penelitian tersebut, artikel ini lebih spesifik membahas pemahaman terhadap teks keagamaan tentang cadar dan jilbab di kalangan mahasiswi IAIN Surakarta serta hubungannya dengan motivasi mereka dalam bercadar.

\section{Metode Penelitian}

Metode yang digunakan dalam penelitian ini yaitu kualitatif fenomenologi. Metode ini digunakan untuk memahami secara mendalam bagaimana pemahaman para responden, terutama para mahasiswa yang menggunakan cadar. Pengumpulan data dilakukan dengan beberapa metode, yaitu observasi, survey dan wawancara mendalam.

Penelitian ini diawali dengan melakukan observasi terhadap perilaku mahasiswi yang bercadar dan dilanjutkan dengan memberikan survei kepada mereka. Hasil survei ini kemudian didiskusikan dalam sebuah Forum Group Discussion yang tidak hanya diikuti para informan tersebut, tapi juga mahasiswi yang tidak bercadar serta juga mahasiswa. Setelah ini peneliti melakukan wawancara mendalam secara acak terhadap 7 orang mahasiswi bercadar. Hasil 
temuan penelitian kemudian dianalisa secara kualitatif yang terkait relevansi pemahaman para responden tentang hukum bercadar dan faktor-faktor yang paling berpengaruh terhadap pemakaian cadar di kalangan mereka.

\section{Pandangan Mahasiswi atas Makna dan Praktik Bercadar}

Setelah melalui observasi dan survei, peneliti melakukan wawancara mendalam terhadap 7 orang responden. Dari hasil wawancara, Responden 1, berpendapat bahwa hukum memakai cadar adalah sunah muakkadah. Dia merujuk pada pandangan madzhab Syafi'i yang tertuang dalam Kitäb Safina alNajāh dalam bab tentang aurat perempuan. Responden 1 juga mengaku paham dengan asbab al-nuzul ayat-ayat tentang menutup aurat meskipun tidak menjelaskannya. Ia juga mengaku mengerti sejarah pemakaian cadar pada masa Yahudi. Sayangnya, Responden 1 tidak menjawab pertanyaan dari mana ia belajar hukum tentang memakai niqab.

Responden 1 juga memahami bahwa ada banyak perbedaan pendapat tentang pemakaian cadar. Ia bisa memahami jika ada Muslimah yang tidak memakai cadar karena bagi Responden 1 memakai cadar bukan merupakan kewajiban, tapi dalam hukum fiqh masuk dalam kategori sunah. Baginya, perbedaan pendapat tentang memakai cadar tidak boleh dipertentangkan. Semua perbedaan tersebut harus selalu dilihat dari konteksnya. Selain itu, Responden 1 memandang perlunya kearifan dalam menyikapi perbedaan pendapat tersebut. Ketidakwajiban memakai cadar nampak pada pengakuan Responden 1 bahwa ketika shalat di lingkungan perempuan ia tidak memakai cadar. Tapi jika ada laki-laki di sekitar tempat shalat, maka ia akan shalat dengan tetap memakai cadar.

Lebih lanjut Responden 1 juga menekankan pentingnya kewajiban lakilaki untuk menjaga pandangan. Di sisi lain, ia juga berpedapat tentang pentingnya perempuan untuk selalu menutup aurat. Namun, Responden 1 menganggap bahwa menutup aurat bagi perempuan merupakan upaya perempuan untuk membantu laki-laki dalam menjaga pandangan.

Meskipun bercadar, responden lain yang yaitu Responden 2 berpendapat bahwa memakai cadar hukumnya sunah bagi Muslimah, bukan wajib. Ia merujuk pada madzhab Hanafi yang menilai bahwa hukum bercadar adalah sunah. Namun, menurut Responden 2 sambil tetap merujuk pada madzhab Hanafi, hukum sunah tersebut bisa berubah menjadi wajib jika menanggalkan cadar dinilai akan menimbulkan fitnah. 
Responden 2 tidak menjawab ketika ditanya tentang asbāb al-nuzūl ayat-ayat tentang aurat. Ia juga mengaku tidak tahu sejarah pemakaian cadar sejak masa Yahudi. Pengetahuannya tentang memakai cadar ia peroleh dari guru, namun ia tidak secara spesifik menyebutkan siapa yang dimaksud dengan guru.

Responden 2 juga tidak mempermasalahkan perbedaan pendapat tentang hukum memakai cadar. Baginya, setiap pendapat pasti punya dasar masing-masing. Responden 2 justru kagum dengan kaum Muslimah yang tidak bercadar tapi mampu menutup auratnya dengan sempurna, misalnya dengan menutup kaki dan juga memakai pakaian yang sesuai dengan syariat Islam. Sebaliknya, jika melihat perempuan Muslimah tidak bercadar dan tidak mampu menutup auratnya dengan baik, Responden 2 merasa miris. Ia ingin sekali mengajak mereka atau sekedar mengingatkan agar menurut aurat, namun ia khawatir jika dianggap berlagak suci.

Meski hanya sunah, Responden 2 dengan tetap memakai cadar jika ia melaksanakan shalat di tempat terbuka. Responden 2 juga berpendapat bahwa laki-laki wajib menundukkan pandangan karena mata, menurut Responden 2, adalah sumber dari segala kemaksiyatan.

Meskipun sudah cukup lama memakai cadar, seorang responden yaitu Responden 3 tidak menjawab pertanyaan-pertanyaan seputar hukum memakai cadar dalam fiqh. Ia juga melewatkan pertanyaan tentang asbāb al-nuzūl ayatayat tentang aurat dan sejarah cadar sejak masa Yahudi. Responden 3 juga tidak menjawab pertanyaan tentang di mana ia belajar tentang ketentuan memakai cadar dan perbedaan pendapat tentang hal tersebut.

Namun Responden 3 pada akhirnya menjawab bahwa hukum memakai cadar tidak wajib ketika ia menyatakan bahwa tidak masalah jika ada perempuan yang tidak memakai cadar. Lebih lanjut, Responden 3 menuturkan ketika shalat berjamaah di masjid ada makmum laki-laki, ia akan tetap memakai cadarnya. Namun jika jamaah shalat tersebut terdiri dari makmum perempuan dan hanya ada satu (laki-laki) sebagai imam, maka Responden 3 melakukan shalat dengan tidak memaki cadar. Ia juga setuju dengan kewajiban laki-laki untuk menundukkan pandangan. Namun Responden 3 mengatakan hal tersebut kembali kepada laki-laki apakah akan mengambil yang haq (menundukkan pandangan) dan meninggalkan yang batil. 
Sementara itu, Responden 4 berpendapat bahwa memakai cadar hukumnya adalah mubah. Ia merujuk pada Al-Quran surat an-Nūr ayat 31 sebagai landasannya. Namun Responden 4 mengakui bahwa ia hanya memahami sedikit tentang asbāb al-nuzūl dari ayat-ayat Al-Quran tentang aurat. Ia juga hanya mengetahui sekilas sejarah tentang pemakaian cadar sejak masa Yahudi. Responden 4 mendapatkan pengetahuan dan pemahaman tentang cadar dari buku-buku yang ia baca. Dalam prakteknya, Responden 4 memakai cadar ketika shalat berjamaah di masjid, khususnya ketika tidak ada pembatas antara shaf laki-laki dan shaf perempuan.

Responden 4 juga tidak mempermasalahkan perbedaan pendapat tentang hukum memakai cadar bagi kaum Muslimah. Baginya biasa saja jika ada perbedaan pendapat tersebut. Menurut Responden 4, yang penting adalah menundukkan pandangan dan menjaga agar aurat tidak dilihat oleh yang bukan mahramnya. Menjaga pandangan, bagi Responden 4, tidak hanya berlaku bagi laki-laki, tapi juga untuk perempuan. Keduanya juga wajib menjaga aurat.

Sedangkan Responden 5 berpendapat bahwa hukum memakai cadar adalah mubah. Ia merujuk pada Al qur'an surat an-Nisā dan al-Baqarah sebagai landasan, namun Responden 5 tidak menjelaskan ayat mana yang menunjukkan landasan yang ia pakai untuk bercadar. Responden 5 juga mengaku paham tentang asbāb al-nuzūl ayat-ayat Al-Quran tentang aurat dan juga tentang sejarah Niqab dari masa Yahudi. Ia mengetahui ketentuan tentang memakai cadar dari guru mengajinya.

Responden 5 juga tidak mempermasalahkan perbedaan pendapat tentang ketentuan memakai cadar. Baginya, perbedaan tidak seharusnya menjadi sumber perpecahan, tapi justru sebagai alat pemersatu bangsa. Orang yang memilki keyakinan untuk memakai cadar juga tidak boleh dilarang. Semua itu kembali kepada niat masing-masing. Oleh karena itu, Responden 5 juga tidak mempermasalahkan Muslimah yang tidak memakai cadar. Seseorang dianggap musliman bukan karena ia memakai cadar atau jilbab, tapi menurut Responden 5, karena di dalam dirinya ada akhlak sebagai seorang Muslimah. Karena paham bahwa memakai cadar adalah mubah, Responden 5 tetap memakai cadar ketika ke masjid, tapi melepaskannya ketika sedang mengerjakan shalat di masjid. Ia juga setuju dengan ketentuan dalam Islam bahwa laki-laki dan juga perempuan wajib menundukkan pandangan ketika berhadapan dengan lawan jenis yang bukan mahramnya. Responden 5 merujuk kepada Al qur'an sebagai landasan kewajiban untuk menundukkan pandangan. 
Meskipun demikian, Responden 6 juga sadar bahwa hukum memakai cadar bukan wajib, melainkan sunah. Ia paham bahwa tidak ada hukum yang secara pasti mengatakan bahwa memakai cadar adalah sesuatu yang wajib. Bahkan ia menjelaskan bahwa ketika shalat wajah harus terbuka, yang artinya tidak memakai cadar ketika sedang mengerjakan shalat. Karena menganggapnya tidak wajib, Responden 6 juga melepas cadarnya ketika ia mengerjakan shalat di masjid.

Responden 6 merujuk pada sebuah hadis yang meriwayatkan bahwa Aisyah istri Nabi menggunakan Niqab sebagai penutup wajahnya sebagai landasan ia memakai cadar. Terkait dengan ayat-ayat Al-Quran tentang perintah menutup aurat, Responden 6 memahami bahwa perempuan diperintahkan menutup aurat dengan menjulurkan hijabnya untuk membedakan dengan perempuan Yahudi dan juga hamba sahaya. Perintah menjulurkan hijab ini dipahami oleh Responden 6 sebagai cara Islam untuk memuliakan kaum Muslimah dengan membedakan mereka dari perempuan Yahudi yang berpakaian sesuai keinginan mereka sendiri.

Responden 6 mengaku tidak banyak mengetahui tentang sejarah cadar pada masa Yahudi. Yang ia ketahui adalah perempuan Yahudi pada zaman dahulu memakai cadar karena letak geografis Timur Tengah yang ada di gurun pasair sehingga mereka melindungi dan menutup wajah dari debu dan pasir dengan cara memakai cadar. Responden 6 belajar tentang ketentuan memakai cadar dari teman dan kakak kelasnya yang sudah bercadar. Ia juga belajar dari ustadzah tentang ketentuan memakai cadar.

Responden 6 menghargai perbedaan pendapat kaum Muslimah tentang cadar karena menurutnya para ulama juga memiliki pandangan yang berbedabeda tentang memakai cadar. Maryam tidak membeda-bedakan dalam berteman. Ia bisa bergaul dengan siapa saja, baik yang memakai cadar maupun yang tidak. Responden 6 juga tidak mempermasalahkan pandangan yang menganggap memakai cadar adalah terlalu berlebihan dalam agama. Baginya, memakai cadar adalah bentuk keinginan untuk selalu taat kepada Allah, dan Allah Maha Mengetahui segala isi hati orang. Responden 6 juga tidak mempermasalahkan Muslimah yang tidak memakai cadar. Hal itu menurut Responden 6 bukan sesuatu yang salah. Tiap Muslimah memiliki hak untuk memakai cadar atau tidak karena menurutnya cadar memang tidak wajib untuk dipakai. Yang terpenting bagi Responden 6 adalah setiiap Muslimah diharapkan mampu menjaga diriya sebaik mungkin hanya untuk Allah semata, dan bukan untuk manusia. 
Responden 6 juga berpendapat bahwa laki-laki harus menundukkan pandangan terhadap lawan jenis. Seringkali, kata Responden 6, laki-laki mengarahkan pandangannya pada sesuatu yang tidak seharusnya mereka lihat. Oleh karena itu, menurut Responden 6, kaum perempuan juga perlu menjaga dirinya agar tidak menjadi pusat perhatian laki-laki. Sedangkan responden bernama Responden 7 berpandangan bahwa hukum memakai cadar adalah sunah. Ia merujuk kepada madzhab Maliki yang berpendapat bahwa wajah wanita bukan aurat. Namun madzhab Maliki berpandangan bahwa memakai cadar disunahkan (dianjurkan). Hukum ini bisa berubah menjadi wajib jika dikhawatirkan menimbulkan fitnah. Sebagian ulama Maliki bahkan berpendapat bahwa seluruh tubuh perempuan adalah aurat.

Responden 7 juga menyitir pendapat Ibnu Khuwayzi Mandād, salah seorang ulama dari Madzhab Maliki, yang menyatakan bahwa jika kecantikan seorang wanita dapat menimbulkan fitnah, maka perempuan tersebut hendaknya menutupi wajahnya tersebut. Namun sebaliknya, jika wajah seorang perempuan diyakini tidak akan menimbulkan fitnah, misalnya seorang perempuan tua atau wajahnya tidak terlalu cantik, menurut Ibnu Khuwayzi Mandād, sebagaimana disampaikan Responden 7, maka perempuan tersebut boleh menampakkan wajahnya. Sementara itu, menurut Responden 7, madzab Syafi'i berpendapat bahwa aurat wanita di depan lelaki ajnabi (bukan mahram) adalah seluruh tubuh. Sehingga mereka mewajibkan wanita memakai niqab di hadapan lelaki ajnabi.

Responden 7 juga mengaku paham dengan asbāb al-nuzūl ayat-ayat tentang ketetuan menutup aurat. Ia juga mengerti sejarah pemakaian cadar sejak masa Yahudi. Namun Responden 7 tidak menjelaskan di mana ia belajar tentang ketentuan pemakaian cadar. Ketika ada perbedaan pendapat tentang hukum memakai cadar, Responden 7 mengatakan untuk saling menghormati, tidak mencela atau bahkan saling menjauhi. Oleh karena itu, ia juga tidak mempermasalahkan muslimah yang tidak memakai cadar. Ia menegaskan bahwa memakai cadar adalah sunah yang penting bagi Responden 7 adalah mereka berhijab yang menutup dada, tidak ketat dan juga tidak transparan.

Cadar tidak selalu dipakai, ketika menjalankan shalat di masjid atau tempat umum, Responden 7 terkadang melepaskan cadar. Namun ia juga kadang hanya mengendorkannya sedikit sehingga nampak hidung dan mulut. Terkait dengan kewajiban laki-laki untuk menundukkan pandangan, Responden 7 menyatakan sangat setuju. Selain karena hal tersebut merupakan perintah di dalam al-Quran, Responden 7 juga berpendapat bahwa 
menundukan pandangan dapat melindungi diri dari penglihatan dan keinginan hati yang akan berdampak buruk, sehingga cadar merupakan suatu yang bisa bermanfaat dalam pribadi pemakai.

\section{Relevansi Pemahaman tentang Hukum Bercadar dan Praktek Bercadar}

Paparan para responden yang telah diwawancarai, dapat disimpulkan bahwa para responden penelitian ini sangat paham tentang hukum dan kedudukan memakai cadar dalam Islam. Para responden yang menyebut bahwa memakai cadar adalah bukan sebuah kewajiban bagi para perempuan muslim. Mereka menyatakan bahwa memakai cadar kedudukannya adalah sunah, yang berarti jika dilakukan akan mendapatkan pahala, dan jika tidak dilakukan tidak menimbulkan dosa.

Para responden juga sadar bahwa memang di dalam fiqh, para ulama berbeda pendapat tentang hukum memakai cadar. Pengarang kitab Kifayatul Akhyar, Imam Taqiy ad-Din Abu Bakr bin Muhammad al-Husayni ad-Dimasyqi ash-Shafi'i (w. 752 H), adalah salah seorang ulama yang mewajibkan cadar. Beliau menyatakan bahwa perempuan boleh tidak memakai cadar hanya ketika berada di dalam masjid. Namun jika di dalam masjid ada laki-laki yang dikhawatirkan tidak bisa menjaga pandangannya, maka Imam Taqiy ad-Din melarang perempuan untuk membuka cadarnya (Al-Hushni, 2001).

Sementara itu, Sayyid Abu Bakr Uthman bin Muhammad Shața adDimyați ash-Shafi'i (w. 1310 H) dalam kitab I'anatu al-Ṭalibin menyatakan bahwa tidak diwajibkan bagi perempuan untuk memakai cadar bahkan ketika mereka berada di jalan. Beliau menyatakan bahwa memakai cadar adalah sunah. Yang lebih penting bagi beliau adalah laki-laki yang seharusnya wajib untuk menjaga pandangan dari melihat perempuan yang bukan mahram. Sehingga, menurut dia, menutup wajah hanya sebuah anjuran untuk kemaslahatan dan untuk menghindari fitnah (Ash-Shafi', n.d.). Sedangkan Abu Dawud Sulaymān bin 'Umar al-Ujayli al-Jamal (w.1204 H) dalam kitab Hashiya al-Jamal mengutip pendapat Qaḍī 'Iyaḍ bahwa perempuan tidak ada kewajiban untuk menutup wajahnya. Sebaliknya laki-laki wajib untuk menundukkan pandangan dari melihat perempuan yang bukan mahramnya.

Ketentuan tentang cadar juga disikapi berbeda-beda antara satu madzhab dengan madzhab yang lain. Madzhab Hanafi menyatakan bahwa wajah perempuan bukanlah aurat. Namun, memakai cadar hukumnya dianjurkan (sunah). Anjuran ini bisa berubah menjadi wajib jika ada 
kekhawatiran tanpa bercadar bisa menimbulkan fitnah. Imam Muhammad Alauddin menganalogikan dengan aurat perempuan. Bahwa yang boleh terlihat adalah wajah dan telapak tangan bagian dalam, meski ada juga yang berpendapat bahwa telapak tangan luar juga bukan termasuk aurat. Namun jika dikhawatirkan menimbulkan fitnah, maka tidak diperbolehkan untuk memperlihatkan wajah di hadapan laki-laki yang bukan mahramnya (Abdul Karim, 2019).

Madzhab Maliki memiliki pandangan yang sama dengan para ulama madzhab Hanafi, seperti az-Zarqani, al-Fakihani dan al-Qalsyani. Mereka menyatakan bahwa sebagaimana aturan tentang aurat, maka perempuan boleh menampakkan wajah dan telapak tangan untuk dilihat laki-laki yang bukan mahramnya. Bahkan melihat wajah perempuan yang masih muda pun boleh misalnya untuk sekedar melihat dan tujuan pengobatan. Tapi jika melihatnya untuk bersenang-senang atau cenderung menimbulkan fitnah, maka hukumnya haram untuk memperlihatkan wajah (Abdul Karim, 2019).

Sedangkan para ulama madzhab Syafi'i mengatakan bahwa aurat perempuan di depan lelaki ajnabi (yang bukan mahramnya) adalah seluruh tubuh. Oleh karena itu, para ulama madzhab Syafi'i menyatakan wajib hukumnya bagi para perempuan untuk memakai cadar di hadapan laki-laki yang bukan mahramnya. Ash-Sharwani membagi tiga macam aurat perempuan, yaitu aurat dalam shalat yaitu seluruh badan kecuali wajah dan telapak tangan; aurat terhadap laki-laki bukan mahram yaitu seluruh tubuh termasuk wajah dan telapak tangan; dan aurat ketika berdua bersama mahram yaitu sama seperti laki-laki, yaitu antara pusar dan paha.

Salah seorang ulama dari madzhab Hanbali yang bernama Abdallah bin Abd al-Aziz al-Anqari berpendapat bahwa aurat perempuan baligh adalah seluruh tubuh kecuali wajah karena wajah bukanlah aurat di dalam shalat. Adapun di luar shalat, semua bagian tubuh adalah aurat, termasuk pula wajahnya jika di hadapan lelaki atau banci. Jika di hadapan sesama wanita, auratnya antara pusar hingga paha. Oleh karena itu, secara umum para responden menjadikan niat ibadah sebagai motivasi utama di dalam bercadar. Mereka mengetahui dan menyadari bahwa ada perbedaan pendapat tentang hukum bercadar sehingga mereka tidak mengajak orang lain yang tidak bercadar untuk memakai cadar. Mereka juga tidak mempersoalkan jika ada yang memandang sinis terhadap keputusan mereka bercadar. 
Kesadaran akan tidak wajibnya bercadar ini terlihat antara lain ketika mereka berada di kampung halaman mereka, atau berada di tengah-tengah keluarga mereka, ada di antara mereka yang tidak memakai cadar. Salah satu alasan dari responden adalah ridha orang tua mereka untuk memakai cadar adalah ketika mereka jauh dari keluarga. Begitu juga mereka siap melepas cadar mereka jika suami mereka menghendaki mereka untuk tidak memakai cadar. Sama dengan alasan terhadap orang tua, bagi mereka ridha dan berbakti kepada suami adalah sebuah kewajiban yang posisinya berada di atas memakai cadar yang sunah. Hal ini mengkonfirmasi bahwa pengamalan ajaran agama bagi perempuan terkadang tergantung pada aspek domestik, yaitu ijin dari orang tua maupun suami (Hassan, 2002; Husna, 2018; Wardhani, 2008). Oleh karena itu, selain motivasi ibadah, yang memperkuat mereka untuk memakai cadar adalah faktor perlindungan diri dalam pergaulan di dalam masyarakat, khususnya dengan lawan jenis.

Banyak di antara para responden yang menganggap cadar adalah alat keamanan yang dapat melindungi mereka dari gangguan dan godaan lawan jenis. Ada di antara responden yang niat memakai cadar menguat karena ia tinggal jauh dari kampus dan terkadang sering pulang hingga larut malam. Dengan kondisi seperti ini, motivasi bercadar selain memang untuk beribadah juga melindungi diri dari gangguan-gangguan yang mungkin dating khususnya ketika ia sendirian. Konstruk sosial yang kuat ini menggambarkan bagaimana agama dan kehidupan sosial berkelindan, biasanya dalam bentuk agama melegitimasi konstruk sosial (Cahyaningrum \& Desiningrum, 2017; Hassan, 2002; Turner, 1991). Secara spesifik, legitimasi agama untuk tubuh sangat kuat di mana perempuan dalam berpakaian sangat tergantung pada bagaimana agama mengkonstruknya (Arthur, 2000; Novri \& Yohana, 2016; Wagner et al., 2012; Zempi, 2016). Ada juga responden yang lain yang niat memakai cadar semakin kuat ketika ia sering mendapat godaan dari lawan jenis ketika berada di kampus. Awalnya ia sudah memakai cadar namun tidak setiap waktu. Adakalanya ia hanya memakai masker sebagai ganti cadar. Namun ketika ia sering mendapat godaan dari laki-laki, bahkan teman sekelasnya, maka ia memutuskan untuk memakai cadar seterusnya.

Di sini juga nampak perempuan tidak berkuasa atas tubuhnya. Persepsi orang luar, khususnya laki-laki, menjadi penting bagi perempuan dalam berpakaian (Arthur, 2000; Bilge, 2010; Fitriyah, 2018; Pratiwi \& Martiarini, 2020; Shirazi \& Mishra, 2010; Wagner et al., 2012; Zempi, 2016). Selain itu, penggunaan cadar dari para responden ternyata tergantung tempat. Mereka 
lebih sering memakai cadar ketika di ranah public, atau di tempat-tempat di mana mereka bergaul dengan orang yang sebagian besar tidak mereka kenal (Cahyaningrum \& Desiningrum, 2017; Tissot, 2011; Zempi, 2016).

Aspek perlindungan ini hampir terjadi di setiap responden. Masih kuat anggapan bahwa tubuh mereka memiliki daya tarik seksual yang dapat menimbulkan fitnah, yaitu membuat lawan jenis tertarik (Arthur, 2000; Bilge, 2010; Shirazi \& Mishra, 2010; Wagner et al., 2012). Perempuan bercadar yang menjadi responden penelitian ini masih melihat bahwa perempuan secara umum adalah obyek seksualitas laki-laki. Meskipun mereka sadar bahwa semestinya laki-laki juga menundukkan pandangan sebagai penerapan perintah agama, namun para responden merasa lebih aman dan nyaman melindungi wajah mereka dengan cadar sehingga tidak membuat laki-laki menggoda atau tertarik kepada mereka secara fisik.

\section{Kesimpulan}

Motif utama para muslimah dalam menggunakan cadar adalah untuk melaksanakan ketentuan syariat Islam untuk menutup aurat, namun bagi sebagian yang lain, ada faktor-faktor non-keagamaan yang lebih mempengaruhi mereka untuk bercadar. Penelitian ini menemukan bahwa di antara para mahasiswi IAIN Surakarta yang memakai cadar, wajah bisa menjadi aurat karena bisa menimbulkan fitnah dan godaan bagi lawan jenis. Salah satu faktornya adalah semua responden dalam penelitian ini mengetahui dan menyadari bahwa memakai cadar bukanlah sebuah kewajiban. Mereka memahami bahwa ada perbedaan pendapat di kalangan ulama mengenai hukum mengenakan cadar. Namun mereka mengambil pendapat yang menyatakan bahwa memakai cadar adalah sunah (dianjurkan). Pengetahuan agama tentang hukum memakai cadar ini didapatkan ketika mereka mengikuti kajian atau pengajian, maupun ketika mereka duduk di bangku sekolah SMP atau SMA, karena sebagian di antara mereka ada yang sudah pernah memakai cadar ketika SMP. Motif non-keagamaan dalam pemakaian cadar di antara para responden ini menjadi faktor yang memperkuat niat mereka untuk bercadar, selain motif keagamaan yang bersifat umum. 


\section{Referensi}

'Audah, Ḥasan. (2000). al-Mar'a al-'Arabiyya fĩ al-Dīn wa al-Mujtama.' al-Ahalī.

Abdul Karim, S. (2019). Pemakaian Cadar Dalam Perspektif Mufassirin Dan Fuqaha'. Al-Mu'Ashirah, 16(1).

Al-Hushni, T.-D. A. B. M. (2001). Kifāyat al-Akhyār. Dār al-Kutub al-'Ilmiyya.

Arthur, L. B. (2000). Religion, Dress, and the Body. Oxford International Publisher.

Ash-Shafi', S. A. B. U. b. M. S. ad-D. (n.d.). I'ānat al-Ṭālibīn. Dār Iḥyā’ al-Kutub al'Arabiyya.

Bilge, S. (2010). Beyond subordination vs. resistance: An intersectional approach to the agency of veiled muslim women. Journal of Intercultural Studies. https://doi.org/10.1080/07256860903477662

Cahyaningrum, D., \& Desiningrum, D. (2017). Jiwa-Jiwa Tenang Bertabir Iman: Studi Fenomenologi Pada Mahasiswi Bercadar Di Universitas Negeri Umum Kota Yogyakarta. Empati: Jurnal Karya Ilmiah S1 Undip.

Dewi, P. A. R. (2019). Niqab Sebagai Fashion: Dialektik Konservatisme Dan Budaya Populer. Scriptura, 9(1), 9-15. https://doi.org/10.9744/scriptura.9.1.9-15

Fitriyah, A. (2018). Makna Tubuh bagi Mahasiswi Bercadar di Yogyakarta: Kajian Sosiologi Tubuh. FIKRAH. https://doi.org/10.21043/fikrah.v6i2.4008

Harahap, S. A. (2019). Studi Komparatif Fatwa Yusuf Qardawi Dan Syaikh Utsaimin Tentang Hukum Bercadar (Menutup Wajah). ADLIYA: Jurnal Hukum Dan Kemanusiaan. https://doi.org/10.15575/adliya.v12i1.4488

Hassan, R. (2002). Faithlines; Muslim Conceptions of Islam and Society. Oxford University Press.

Husna, F. (2018). Niqab Squad Jogja Dan Muslimah Era Kontemporer Di Indonesia. AlBayan, 24(1).

Novri, M. S., \& Yohana, N. (2016). Konstruksi Makna Cadar Oleh Wanita Bercadar Jamaah Pengajian Masjid Umar Bin Khattab Kelurahan Delima Kecamatan Tampan Pekanbaru. Jurnal Online Mahasiswa Fakultas Ilmu Sosial Dan Ilmu Politik.

Pratiwi, S. R., \& Martiarini, N. (2020). "Bagaimana Mereka Mengubahku?" (Interpretative Phenomenological Analysis tentang Rekonstruksi Identitas pada Muslimah Bercadar). Intuisi : Jurnal Psikologi Ilmiah. https://doi.org/10.15294/intuisi.v12i1.18326

Rahman, A. F., \& Syafiq, M. (2017). Motivasi, Stigma dan Coping Stigma pada Perempuan Bercadar. Jurnal Psikologi Teori Dan Terapan. https://doi.org/10.26740/jptt.v7n2.p103-115

Rasyid, L. A., \& Bukido, R. (2018). Problemtika Hukum Cadar Dalamislam: Sebuah Tinjauan Normatif-Historis. Jurnal Ilmiah Al-Syir'ah. https://doi.org/10.30984/jis.v16i1.648

Saleh, S. R., Pakaya, N. A., \& Doni, C. P. (2019). Pembentukan Identitas Keagamaan Mahasiswi Bercadar Di Perguruan Tinggi Agama Islam Di Gorontalo. Madani. 
Shirazi, F., \& Mishra, S. (2010). Young Muslim women on the face veil (niqab): A tool of resistance in Europe but rejected in the United States. International Journal of Cultural Studies. https://doi.org/10.1177/1367877909348538

Tissot, S. (2011). Excluding Muslim women: From hijab to niqab, from school to public space. Public Culture, 23(1), 39-46. https://doi.org/10.1215/08992363-2010-014

Turner, B. S. (1991). Religion and Social Theory (2nd ed.). Sage Publication.

Ulumuddin, I. K. (2020). Niqab (Cadar) Dalam Perspektif Hukum Islam. In SOSIO DIALEKTIKA.

Vristiandani, I. F., \& Rakhmad, W. N. (2019). Studi Semiotika Representasi Identitas Selebgram Perempuan Bercadar dalam Media Sosial Instagram. Jurnal Interaksi Online.

Wagner, W., Sen, R., Permanadeli, R., \& Howarth, C. S. (2012). The veil and Muslim women's identity: Cultural pressures and resistance to stereotyping. Culture and Psychology, 18(4), 521-541. https://doi.org/10.1177/1354067X12456713

Wardhani, F. Y. (2008). "Permasalahan dan Penyesuaian Diri pada Pernikahan Wanita Muslimah Berjilbab dan Bercadar." Anima, Indonesian Psychological Journal, 23(3), 227-236.

Yusra, N. (2013). Pendidikan Adab Berpakaian Wanita Muslimah: Telaah Hadist Nabi Tentang Berpakaian. Marwah: Jurnal Perempuan, Agama Dan Jender. https://doi.org/10.24014/marwah.v12i1.514

Zempi, I. (2016). 'It's a part of me, I feel naked without it' ': choice, agency and identity for Muslim women who wear the niqab.' Ethnic and Racial Studies, 39(10), 1738-1754. https://doi.org/10.1080/01419870.2016.1159710

Zulfa, Y., \& Junaidi, A. (2019). Studi Fenomenologi Interaksi Sosial Perempuan Bercadar di Media Sosial. Koneksi. https://doi.org/10.24912/kn.v2i2.3947 
This page intentionally left blank 